\title{
РЕГІОНАЛЬНА ВІДПОВІДАЛЬНІСТЬ ПЕРЕД УКРАЇНОЮ ТА ГЛОБАЛІЗАЦІЯ СОЦІОГУМАНІСТИЧОЇ ПАРАДИГМИ МІЖНАРОДНИХ ВІДНОСИН
}

\author{
Степан ВОВКАНИЧ \\ ДУ "Інститут регіональних досліджень ім. М. І. Долішнього НАНУ" \\ Відділ регіональної економічної політики \\ вул. Козельницька, 4, Львів, 79026, Україна \\ e-mail: irr@mail.lviv.ua
}

\begin{abstract}
У статті звернено увагу на те, що за умов ескалації Росією гібридної війни проти України дедалі більше актуалізується нагальність потреби глобалізації соціяльно-економічної, духовноінформаційної, етнокультурної, політично-правової та иншої відповідальности Заходу перед Україною в системі верифікації нової соціогуманістичної парадигми міжнародних відносин та використання для цього синергійного ефекту цивілізованого людства, отриманого від колективної мобілізації його зусиль на протистояння сучасним імпершовіністичним викликам світовому правопорядку, агресіям на суверенітет і суб'єктність ослаблених націй. Ці нації, окрім того, що недостатньо обороноспроможні і захищені від добре озброєного загарбника, ще потерпають від його злочинно-підступного, гібридно-дезінформаційного голосу, який робить їх безголосими i прирікає бути вічно недочутими.
\end{abstract}

Ключові слова: історична відповідальність перед Україною, національна ідея, соціогуманістична парадигма, стратегеми і максими розвитку країни.

Шість років гібридної війни Росії проти України вплинули не лише на структуру і темпи розвитку ії економіки, соціяльних процесів, а й дедалі більше змінюють ставлення світового співтовариства до ролі України в історичному і сучасному вимірах. “Якби мені п'ять років тому сказали, що ми говоритимемо про історичну відповідальність Німеччини, й у німецькому бундестазі буде така дискусія, я б не повірила, тому що п'ять-сім років тому в Німеччині важко було говорити навіть про якусь участь або роль України як серйозного гравця під час Другої світової війни", - сказала в Києві послиня України в Німеччині (2008-2011) Наталія Зарудна. Ідеться про іiї реакцію на промову відомого американського історика Тімоті Снайдера "Історична відповідальність Німеччини перед Україною” в Бундестазі ФРН ${ }^{1}$, а також на обговорення зазначеної проблеми у ВР України під час міжнародної конференції “Німеччина та Україна в Европі: відповідальність за минуле - обов'язки на майбутнє"2.

\footnotetext{
${ }^{1}$ Тімоті Снайдер, “Історична відповідальність Німеччини перед Україною”, День, o. 115116, (2017).

${ }^{2}$ Наталя Пушкарик, “Про помилки минулого і ...сьогодення” (Матеріали міжнародної конференції ВР України “Німеччина та Україна в Європі: відповідальність за минуле - обов'язки на майбутнє", 2017).
} 
ISSN 2078-6077. Наукові зошити історичного факультету Львівського університету. 2020. Випуск 21. Proceedings of History Faculty of Lviv University. 2020. Issue 21.

Передусім важливим є те, що ці заходи, що чи не вперше торкнулися актуальної проблеми відповідальности перед Україною не в тлумаченні українців. Закордонні вчені спробували серйозно розглянути категорію відповідальности не 3 позиції їх претензій, а значно глибше і глобальніше. Щоправда, американський учений обмежився лише історичним і німецьким контекстом. Іще істотний нюанс: позаяк обговорення відбулися у час літніх канікул, то, як свідчать спостереження, ця важлива не лише для України проблематика може стати одноденкою, розчинившись у поточному медійному і науковому просторах ${ }^{3}$. Адже і після канікулярного затишшя тематична турбулентність, спричинена відповідальністю Німеччини за гібридну війну Росії, не сколихнула інформаційно-наукового евроатлантичного світу. Це не має дивувати, бо “на жаль, - зазначив в Києві представник Інституту евроатлантичного співробітництва Андрес Умланд, - досі в Німеччині немає інституту, який би займався Україною, а в Україні німецького університету"4. Отже, дефініція "відповідальність перед Україною" в умовах гібридної війни Путіна охоплює не лише Німеччину і потребує широкої концептуалізації.

\section{Захід завжди платив Росії данину - Украӥною}

Для майбутнього суспільного прогресу засадниче значення має рефлексія послині Н. Зарудної: “Я хотіла б дожити до того дня, коли ми говоритимемо про історичну відповідальність не тільки Німеччини, а й Росії за всі ті народи, які вона пригноблювала і продовжує вважати меншовартісними". Проте, з огляду на “універсальну точку зору”, яку заартикулював в Берліні Т. Снайдер,претендуючи на комплексне охоплення періоду Другої світової війни і сучасних воєнних дій гібридної війни Росії на сході України, - він, як фахівець 3 історії Східної Европи, зокрема тоталітарних режимів, мав би, на наш погляд, ширше та істотніше донести світові сенси нинішньої боротьби українців на Донбасі. Адже у час ескалації загроз глобалізації гібридної війни це стає планетарним, - і може мати критичні наслідки - Росія може розв'язати Третю світову війну.

Керівник Центру ліберальної сучасности Рудольф Фюкс зауважив, що “дуже важливе сприйняття України не лише як жертви, але як нації, що має власну культуру, історію, економіку, щоб вона розумілася як суб'єкт історії, а не лише об’єкm (підкреслення наше - C. B.) на великій шаховій дошці супердержав". Але "перетопивши" в імперському казані історію України-Руси, сподобавши варварські набіги на давній Київ, неофюрери Росії, не вгамовуються і не заспокоюються. Тому дещо дивними є тези промови американського історика,

\footnotetext{
${ }^{3}$ Степан Вовканич, “Чи лише одна Німеччина відповідальна?”, Україна молода, о. 118 (5279), 3 жовтня 2017.

${ }^{4}$ Наталя Пушкарик, “Про помилки минулого і ...сьогодення" (Матеріали міжнародної конференції ВР України “Німеччина та Україна в Європі: відповідальність за минуле - обов”язки на майбутне”, 2017).
} 
в яких українській нації без неї “втулюється” дуже неоднозначний концепт відповідальности Німеччини не за криваві дії, що ведуть нинішні неофюрери на сході України, а - свідомо чи несвідомо - відповідальність Німеччини перед Україною зводиться до аналізу злочинів, що їх вчинив Гітлер у минулому. Гітлер помер, однак, злочинне тотально-гібридне мінування України і світу ідеологемами російського традиційного імпершовінізму живе, збагачуючись новим контентом і загарбницьким апетитом.

Дедалі очевиднішою стає потреба не лише міжнародного трибуналу "Нюрнберг-2" як запобіжника, що, поряд 3 нацизмом, засудить і покарає більшовизм як людиноненависницьку імперсько-російську загарбницьку ідеологію, особливо українофобську; а й міжнародної зустрічі - “Ялта-2", де вкотре обдурений Захід, набувши нарешті антибільшовицького імунітету, не віддаватиме Україну, як це вже було в 1944 р., в сферу впливу (насправді нищення корінних народів - українців, татар) Росії. Коли українська нація і в XXI ст. стікає кров'ю, то передовсім слід пройнятися тим, щоб зупинити кровотечу, поповнити втрати, а відтак - не допустити подальшого кровопускання на Донеччині, яке і це очевидно вже всім - не що інше, як імперсько-свавільна кара Кремля за непослух бути даниною. Історію вчать чи повинні вчити, аби позбутися помилок “тут і зараз”, і в майбутньому. Це архиважливо - опрацювати стратегію звільнення тимчасово окупованих частин України - стратегії деокупації Донбасу та не допустити, аби замість соборнізації України глобалізувалася злочинна регіоналізація за московськими лекалами в европейському напрямі 5 .

Завдання українських (і не лише) істориків - передовсім довести світові, що маніпулювати і легковажити історію українців, їх націотворення - означає добивати нескорених, яким нині і так важко від нав'язаної гібридної війни. Рани, спричинені анексією Криму, агресією на сході України з боку путінської Росії, кровоточать і потребують нагальної радикальної допомоги. Щоправда, промовець цю очевидну злочинність Росії і хибну розгубленість Заходу згладжує, відразу заявляючи, що почне з універсальної (?) точки зору, з проблем ЕС, “як і кризи демократії та верховенства права в США, спричинених багатьма речами; одна 3 них - це якраз неспроможність дати собі раду з певними аспектами історіі”. Попри те, він не допоміг з'ясувати несправедливості Заходу щодо України, допущені сто років тому в період УНР, ані підчас Другої світової війни. Нічого згадувати хоча б про пунктирне накреслення векторів відповідальности чи проєктів реалізації гарантій країн - підписантів Будапештського меморандуму - як зараз допомоги без'ядерній Україні захиститися, відновити цілісність, зневажені цінності, аби гідно інтегруватися в цивілізований світ.

Шкода, що у промові відсутня будь-яка оцінка відповідальности Заходу, в т.ч. сучасної Німеччини на саміті НАТО в Бухаресті в 2008 році, коли Україні не надали плану дій щодо прийому до евроатлантичного альянсу колективного

\footnotetext{
${ }^{5}$ В. Горбулін, уклад. “Донбас і Крим: ціна повернення” (Київ: НІСД, 2015), 474.
} 
ISSN 2078-6077. Наукові зошити історичного факультету Львівського університету. 2020. Випуск 21. Proceedings of History Faculty of Lviv University. 2020. Issue 21.

захисту. Що, на думку фахівців, могло б унеможливити майбутні воєнні дії Росії проти Грузії чи України. Не згадується й анексія Криму. Недаремне німецький історик і представник Німецького товариства зовнішньої політики Вілфрід Їльге на конференції в Києві відзначив: “Ми повинні думати про те, як можемо допомогти Україні в правовому плані повернути Крим і захистити Україну перед міжнародними інституціями і організаціями, що не можемо миритися з агресією проти Криму і його захопленням, і що, вирішуючи конфлікт, ми не повинні повертатися до питання про сфери розподілу в Европі” 6 . Однак не згадуються не лише помилки минулого, а й прорахунки сьогодення, зокрема потреба своєчасної і адекватної реакції $\mathrm{OOH}$ на анексію Криму, а й у що обходиться українцям гібридна війна на Сході, Заходові - “антитерористична місія” Росії в Сирії, теракти в Парижі, Брюсселі, Англії - важлива низка міграційних проблем, джерельно-пов'язаних із путінським неофюрерством і відновленням “імперії зла". Адже масштаби руйнації від ланцюгової реакції на ці помилки можуть в недалекому майбутньому викликати глобальні катастрофи, доленосні не лише для згаданих країн та міст.

3 такими акцентами України, яку віддавна тероризує Москва, Заходу, котрий тривалий час спостерігає цей великодержавний тероризм, а нині-вже не тільки співчуває, а й допомагає постраждалій стороні, спіч Снайдера, на наш погляд, не заохотить світову громадськість синергійно замислитися над генезою загальносвітових загроз, які дедалі небезпечніше нависають над долею та вартостями цивілізованого людства. Адже через корупцію не розглядається стратегія причин можливостей (чи неможливостей) надати Україні для стабільного розвитку “план Маршалла-2" або ж допомогти іншими довгостроковими соціяльно-економічними, фінансовими, політично-оборонними заходами. Ба більше, не аналізується історична відповідальність національних еліт за результати референдумів у Нідерландах, Великій Британії, за неодностайну підтримку введення економічних санкцій проти Росії, за будову нових північних і південних газопроводів, які, оминаючи Україну, можуть підірвати українську економіку, та ще й посадити Захід на монопольну російську енергетичну голку.

Усе це має змусити українців глибоко замислитися не лише над неефективністю коротких банківських траншів Заходу, причинами корупції в Україні, зрілістю українців як нації, врешті, над короткою історичною пам'яттю Німеччини та інших країн, а й ширше поглянути на проблему: чому евроінтеграційні процеси впродовж 28 -ти років нашої Незалежности так важко набувають континентальної відповідальности та сталого розвитку. Невже тільки страх перед постсовітськими стратегічними ракетами, що залишилися в Україні після розпаду СРСР, а не щирі бажання допомогти їй вирватися з багатовікового

\footnotetext{
${ }^{6}$ Наталя Пушкарик, “Про помилки минулого і ...сьогодення” (Матеріали міжнародної конференції ВР України “Німеччина та Україна в Європі: відповідальність за минуле - обов’язки на майбутнє", 2017.
} 
ярма Росії, справедливо і вільно жити, інтегрувавшись у вільний світ, змусили на світанку здобутої Незалежности приїхати до Києва тодішніх політичних лідерів - Прем'єра Великої Британії Тетчер та Президента США Буша?! Чому позиція Заходу така хитка?

3 огляду на це, вже згадана немовби універсальна точка зору, яку задекларував учений, навряд чи допоможе обіцянкам молоді - активно засвоїти уроки Другої світової війни. Шкода, але мовець далекий від того, аби пригадати Европі і собі істину: Захід знову заспокоївся і втратив реальність, а дух реваншизму не канув у Лету. Зазвичай він традиційно платив данину Росії, приносячи в жертву державну самостійність України. Тому, розглядаючи історичну відповідальність перед Україною, історик мав би серед багатьох причин таких несправедливих реалій, привернути увагу, особливо молоді принаймні до трьох найголовніших. По-перше, Захід ніколи свідомо не вирізняв 3-поміж пріоритетних факторів медіяторську роль і вагу України в структурі стабілізації міжнародної безпеки, яка, за задумами батьків ЕС - де Голля і Аденауера, - мала б простягатися - аж за Урал. По-друге, він ніколи не мав стратегії щодо України як важливого чинника в механізмі поширення евроатлантичних цінностей на евразійські простори. Ба більше, Захід завжди легко засліплювався (чи його засліплювали росіяни) ореолом Москви яко “миротворця” і “захисника" цих цінностей в Україні, Грузії, інших країнах їх панування, де насправді придушувалася свобода, нищилися европейські цінності та цинічно порушувався світовий порядок. По-третє, чи не найприкріше, світ і нині належно не цінує справді інтернаціональний вимір боротьби українців “за нашу і вашу свободу".

Отже, навряд чи варто було упродовж усього виступу наполегливо пригадувати злочини нацистів у Бабиному Яру “не для того, - як самокритично зазначив американський вчений, - щоб помогти Україні”, а щоб допомогти "Німеччині як демократії, бо про них німці, українці й цілий світ вже давно знають. Однак це не допомогло і не допоможе Україні захистити свій державний суверенітет, допоки прийдешні покоління не побачать, що злочинні дії Путіна щодо анексії Криму покарані; допоки не прозвучить каяття провідних країн за те, що для попередження розгулу “зелених чоловічків” своєчасно не були використані наслідки прорахунків, яких припустилися під час насилля Гітлера в Судетах.

Шкода, але світ далі не цінить міжнародного контексту боротьби українців за свободу, як і сто років тому не цінив іï за часів УНР чи ЗУНРу в 19181919 рр., чи на Закарпатті, де Гітлер у 1939 р. розіграв з Угорщиною, Румунією українську карту. Хіба не Польща розстрілювала на Карпатському перевалі українців, які допомагали Августинові Волошину вибороти свободу, і яких Угорщина повертала в Галичину? Вояки УНР допомагали полякам протистояти наступу більшовиків на Варшаву, а далі вояків інтернували, а в 1930 р. влаштували пацифікацію на Західній Україні та організували концтабір “Береза Картузька”. 
ISSN 2078-6077. Наукові зошити історичного факультету Львівського університету. 2020. Випуск 21. Proceedings of History Faculty of Lviv University. 2020. Issue 21.

Ті самі поляки під час народно-визвольних змагань УПА в 1943-1950-х з відома і підтримки Сталіна, дезінформуючи світ і перекручуючи історію, депортували українців, починаючи від 1944, а згодом під час проведення злочинної операції "Вісла". У результаті українські етнографічні райони Польщі (Лемківщина, Надсяння, Холмщина, Південне Підляшшя) перестали існувати. Жителі ж Північного Підляшшя несправедливо і назагал були оголошені білорусами, їм нав'язувалася білоруська мова як літературна, а так звані калакути, тобто українці, які здавна жили на Холмщині, Південному Підляшші, нині повністю полонізовані. Забуті не те, що колишні загрози аншлюсу, а жертви Берлінського муру та Будапештські гарантії безпеки Україні, що добровільно позбулася третього за потугою в світі ядерного потенціялу. Комплексні і послідовні методи гібридної війни знайомі лише українцям. А для Заходу - війна далеко: десь там Росія проти України, плюс якась незрозуміло гібридна, а поруч - затишок, самозаспокоєння.

\section{Москва робить те, щчо й робила}

Росія далі дурить світ, традиційно вимагаючи звичної данини. Чи не час прокинутися і усвідомити перевірену історією істину: апетити Росії ніколи не закінчаться поглинанням лише України? Росія хоче стати центром Евразії, покрити весь европейський континент. Хіба не ясно, що тільки згуртована контрсила світу може ії змусити відмовитися від цього цинічно-схибленого домагання? Очевидно, п. Снайдера мала б турбувати відсутність належної реакції на підступний рашизм як неоімперську шовіністичну модель глобальної імплементації ідеологеми агресивного “русского міра". Як і те, що сильні світу цього і досі не вдосконалили функції Ради Безпеки ООН. Україна сама на передньому краю боротьби з агресором, і не видно намагань позбавити його права вето як постійного члена оонівської РБ, що напав на іншого учасника ООН. Ніхто не поспішає усвідомити очевидну річ: для світу - це не тільки гібридна, а й пілотажна війна, у якій відточуються загарбницько-імперські методи глобального панування божевільної державно-церковної ідеологеми іншого світу “руського”, брехливо-підступного; що “декомпозіцірованіє” України сьогодні на iii Сході, iï федералізація - це фрагментація ЕС завтра. Випробовування українців гібридною війною - це проби Росії глобально розв'язати таку ж, але вже Третю світову.

Натомість упродовж всієї промови пан Снайдер постулює відповідальність Німеччини за відродження українського націоналізму з таким наголосом, що глушиться голос вмираючих на сході України патріотів, які героїчно віддають життя не тільки за свою свободу. Це дисонує навіть з урахуванням поправки, яку він й сам навів - “свою кар'єру я зробив, пишучи про українських націоналістів”. Адже важко погодитися з його рефлексіями: “Україна $є$ причиною війни; якби Гітлер не мав колоніяльної ідеї йти війною у Східну Европу, якби не було такого плану, не могло бути й Голокосту" (?). Його не турбує генеза i 
відмінності (чи схожість) причин неприйняття з боку Третього райху і СРСР України як національної держави в центрі Европи. Для нацистів - вона центр колоніяльної їх політики у Східній Европі; для більшовиків - територія просунення світової революції так званого пролетаріяту на Захід, корінний народ якої належить зросійщити, насправді донищити як державно-самодостатню націю. Щоправда, мовець віддає належне численним жертвам українців, загиблих від нацизму, ідеї Гітлера створити в Східній Європі центр, базований на рабстві колоніяльного режиму нищення і поневолення України. Однак часто - на правах доброго ментора, намагається "збагатити” пам'ять молодих слухачів історичним концептом із арсеналу власних “наукових” відкриттів: “український націоналізм, українські націоналісти (якіє наслідком німецької війни в Східній Европі) були причиною - або однією з причин - великого Голодомору 1932-1933 років”. I не лише Голодомору. “Український націоналізм був однією з причин терору 1937-1938 років". Він був “однією з оприлюднених Сталіним причин депортацій мешканців радянської України (може, й кримських татар?) після Другої світової війни”.

Створюється враження, що, знаючи історичне невігластво Заходу щодо українського державо-елітотворення, компетентний науковець обмежився лишень слушним відзначенням обопільного, наввипередки хитрого бажання нацизму $\mathrm{i}$ більшовизму завоювати Україну. “Якщо серйозно поставитися до відповідальности Німеччини перед Сходом, то слово “Україна" має бути в першому реченні”. Однак, далі він не дотримується цієї істини, не аналізує відмінности (чи схожости) бажань більшовиків і нацистів ні в історичному контексті, ні в сучасних реаліях. У такий спосіб - свідомо чи несвідомо - далі консервує історичну безвідповідальність Заходу перед Україною, який завжди розплачувався з Росією залежністю Києва. Так вчиняючи, нібито виправдовує нинішнє дещо легковажне ставлення до злочинів росіян проти України, не засуджуючи ні мітів Росії про громадянську війну на Сході, ні будівництва Малоросії. Водночас буцімто підтверджує слушність сталої імперської мети у виконанні Путіна, сенс його мотивів і домагань; адже, не завоювавши Україну, золотоверхого Києва - батька городів руських, - світовим гегемоном йому не стати. Якщо німецького командира поліції, коли придушували повстання у Варшавському гето, не покидала, за Снайдером, думка про Україну як житницю, країну молока і меду, то мимоволі спадає на думку: чому ж сучасних і майбутніх путіних не може переслідувати схиблена імперсько-завойовницька мета перевершити чи хоча б зберегти “досягнення" вождя всіх країн і народів генералісимуса Сталіна?! І агресора Путіна можна “зрозуміти” в його авантюрній грі на світовій шахівниці. Якщо московитам удалося безкарно вкрасти ім'я в України-Руси, то чому б тепер Московщині-Росії не стати центром Евразії? Але для цього треба втримати завойовану європейськість, як також не обійтися без вдаваної цивілізованості, без призвичаєння світу до поглинання суверенітету Української держави як норми, хоча історичне коріння українців віддавна в центрі Европи! Мовець не акцентує, що ціна цього адаптованого злочину - знищити 
ISSN 2078-6077. Наукові зошити історичного факультету Львівського університету. 2020. Випуск 21. Proceedings of History Faculty of Lviv University. 2020. Issue 21.

українців як націю. I не допустити цього - історична і сучасна політична, духовноморальна, безпекова та інша відповідальність і місія не лише Німеччини перед Україною, бо доля останньої провіщення того, що може спіткати людство, якщо його знову обдурять і присплять лукаві “вселюдські миротворці" з Кремля! Програють усі, сподіваючись, що Захід, мета якого - безпека, праця і високі стандарти мирного життя для своїх виборців, - “відкопає сокиру”, аби допомогти українцям вибороти хиренну, за Шевченком, довгождану волю. Та чи не найстрашніше станеться, коли фетиш індивідуального м'якого дивана, містечкового гонору погубить гуманність націй і людства, пасіонарність їх духовно-інтелектуальних ідей - здобутків геніїв людської думки і праці.

\section{Що поза людиною і націсю - фарисейство}

Пора зрозуміти вселенський соціогуманістичний сенс слів Івана Франка: “все, що йде поза рамами нації, се або фарисейство людей, що інтернаціональними ідеалами раді би прикрити свої змагання до панування одної нації над другою, або хоробливий сентименталізм фантастів, що раді би широкими “вселюдськими фразами" покрити своє духовне відчуження від рідної нації”7. Росія (царська, біла, червона, православна чи атеїстична) традиційно креативно-злочинно завжди по-імперському синтезувала, збагачувала і фарисейськи використовує і нині ті самі прийоми. У Польщі для комуніста (секретаря чи рядового члена партії), віруючого католика чи ні також на першому місці - “єстем поляк”. Щодо українців, то їх і московити, і поляки жорстоко переслідували за заклики до національного самовизначення, паче того - до визволення, самостійності. Очевидно, що Тімоті Снайдер - не фарисей у любові до своєї нації, але стосовно інших народів і народностей, через його інтелект мав би більше наближати свідомість европейців до потреби глобалізації соціогуманістичного захисту національного відродження всіх уярмлених. Зокрема, допомогти Європі, в т.ч. Німеччині, зрозуміти загрози і виклики українцям через їх подальше національне знеособлення імпершовіністами Росії, найперше, в спосіб тотального нищення їхнього рідного слова як Логосу корінного (титульного) народу, що дав назву державі в центрі Европи. Допомогти широкому суспільному загалові уяснити очевидну істину: споконвічно видимі джерела існування Росії - це агресивні війни, а невидимі - брехня. Для неї завжди і повсюдно сусідній народ - явище нетривале, і його слід повністю його колоніяльно асимілювати як “братній”, що тимчасово займав “нашенську” землю, себто моковську. Украсти ім'я, загарбати цю землю, сусідський дім, відправивши власника в кращому випадку до Сибіру, - опрацьований механізм “обустройства”, реалізації великодержавної ідеї і самодержавної девіяльної поведінки щодо українців, грузинів та інших сусідніх народів.

\footnotetext{
${ }^{7}$ Іван Франко, “Поза межами можливого, зібрання творів у 50 т., № 45: філософські праці. (Київ: Наукова думка, 1986): 284.
} 
Зрозуміло, що п. Снайдерові, який уперше торкнувся, навіть більше, наважився запровадити до наукового обігу дискурс історичної відповідальности Заходу перед Україною, важко було втілити системний розгляд Української Національної Ідеї (УНI) як такої, що розвивалась у ворожому зовнішньому оточенні шовіністично налаштованих великодержавників, з одного боку, а з іншого, - саме вони час від часу на очах світу ділили Україну і в XXI ст. далі діють агресивно. Тобто, окрім відкритих воєн, перманентно ведуть невидиме (приховане гібридне, інформаційне) внутрішнє насилля над українцями задля їх ізоляції, денаціоналізації та асиміляції, цілеспрямовано перешкоджаючи національному самоусвідомленню і самоствердженню в колі світових культур, мов, економік, ринків, цінностей тощо. Це диктує сенс системного підходу до УНІ, який охоплюватиме два етапи іï розвитку. Перший - Українська Ідея яко символ (гасло) національних змагань українців (приміром, “здобудеш Українську державу, або загинеш в боротьбі за неї”); другий - державотворчість (“побудуємо Европу в Україні”), де іії складові стають (мають стати) стратегемами розбудови національної держави та інтеграції в европейське співтовариство

Росія, як і кожен ворог УНІ, насамперед розстрілювала ії носіїв. Аксіомою для нащадків $є$ також, що Росія ніколи не недотримувалася добросусідських відносин з Україною як з рівним самостійним державним суб'єктом, не визнавала національної ідентичністи (тотожністи) українців, проблема гармонійного розвитку яких може бути відрефлексована і сформульована лише в рамках національної Ідеї. Це пояснюється тим, що Москва не може визнати нас, українців, за давню націю, історично закорінену у власну землю, свою самодостатню окремішню мову, відрубну культуру, питомі звичаї, традиції тощо. Щобільше таку, яка незалежно і вільно вибрала інтеграцію в европейське майбутнє. Це, власне, у взаєминах з Києвом є iї шовіністично-великодержавними домінантами, які вирізняли московитів в минулому, а ще більше вирізняють нині. Захід має зрозуміти, що поряд із Росією самостійна держава Андорра - неможлива. Рубікон давно перейдено. Якщо Европа цього не усвідомлює, то американський історик, підкреслюючи німецьку відповідальність у минулому, мав би хоча тезово застерегти українців від помилок у майбутньому, зокрема допомогти їм стати вище партійности, кар'єризму і популізму заради спільної розбудови майбутньої національної держави. Бути націоцентричними, керуватися єдиними соборними інтересами та емерджентно удосконалювати складові ідеї свого українського державотворення, його якісно нових структурнофункціональних стратегем, які диктує XXI cm., - Україна: соборна, українська і гідна цивілізованого людства. Формула СУГ (соборність, українськість, гідність) проєктує візію і місію сучасної національної ідеї, а ії складові слугують своєрідними СУГестіями впливу на опрацювання стратегії

\footnotetext{
${ }^{8}$ Степан Вовканич, “Аксіологія державотворчих процесів за умов соціально-економічних змін: нових викликів і загроз національній безпеці”, Стратегічна панорама, No. 1, (2015): 76-83.
} 
ISSN 2078-6077. Наукові зошити історичного факультету Львівського університету. 2020. Випуск 21. Proceedings of History Faculty of Lviv University. 2020. Issue 21.

розвитку модерної держави України, через механізм емерджентности якісно поліпшуючи ії як систему, тобто як суспільну систему, для якої людина, нація і цивілізований світ стануть триєдиним підгрунтям, а складові СУГ засадничими маркерами і орієнтирами поступу, випробуваними впродовж тривалого історичного часу всіма цивілізованим державами. Передовсім ідеться про поступ духовний, який передбачатиме не лише територіяльно-просторову, а й духовну соборність українців - їх єдність і спроможність разом, толокою, синергійно творити власну державу на нових ідеологічно-цивілізаційних засадах, консолідуючись і об'єднуючись національно. Себто розвиватися на засадах, які дають змогу зберегти національну ідентичність (тотожність) у системі аксіологічних (ціннісних) аспектів цивілізованости, що емерджентно забезпечують по-сучасному якісні процеси інтелектуалізації, гуманізації, елітаризації та екологізації розвитку культурного розмаїття світу.

Такий широкий системний підхід до відбору націотворчих факторів дає підстави порівнювати, наскільки той чи інший народ сконсолідований внутрішньо та інтегрований у зовнішній світ як єдина спільнота; наскільки він свідомо ідентифікований, а інформаційно (освітньо і науково) підготований як нація, котрій притаманні ознаки цих трьох “i”" цивілізаційного розвитку; як ефективно використовує їх для розбудови своєї держави. Тут важливим $є$ не лишепроцеси, як звично планувати та прогнозувати, використовуючи державотворчі чинники, а й новітньо стратегізувати, що грунтується на верифікації складових національної ідеї як стратегем розвитку, невід'ємних від коротко-, середньо- і довготривалих планів розбудови держави, її канви. Отже, стратегеми - це генеральні напрямні державотворення, за дорожньою картою яких має рухатись $i$ самовіддано працювати нація, аби не провалитися (чи аба ї̈ не перекинули, найперше сусіди) в небуття. У цьому випадку максими розбудови - це фундаментальні світоглядні принципи, які проєктують вектор поступального руху нації, іiі ціннісні орієнтації, тобто служать дороговказами суспільного руху об'єднаних громад і спільноти загалом. Себто руху до бінарного соціогуманістичного захисту і людини, і нації; до гармонії загальнолюдських, европейських і українських цінностей, яким не властиво насильно домінувати на кшталт евразійського-тоталітарного "русского міра" як шовіністичної ідеології загарбання чужих земель, культур, майна, активів тощо. Українці на Майданах кров'ю довели, що в умовах агресивного оточення не дестабілізують світовий порядок, а вибирають канву цінностей цивілізованого людства; сповідують не ядерні амбіції тоталітарно-злочинних режимів 3 їх терористичними актами, гібридними війнами, розпалюванням сепаратизму, шовіністичного націоналізму, а поважають соціяльну справедливість, суверенітет народів і права кожної людини.

Отже, упереджено не заносьмо українців ще раз на “чорну дошку” ідеології націоналізму, щобільше - довоєнного. Це ідеологія поневоленого народу, яка практично історично відійшла в минуле разом з їі авторами - топовими загарбниками XX ст. Їй, власне, притаманна жорстокість, що започаткували 
більшовизм, фашизм, нацизм як доктрини державного нищення “інших” народів, загарбаних мілітарними силами цих людиноненависницьких систем. При них використання алгоритму реалізації національної ідеї поневолених українців у форматі нинішньої соціогуманістичної формули СУГ було, за І.Франком, - “поза межами можливого". Навіть сьогодні, коли в Росії відроджується тоталітаризм, існує загроза втратити шанс на самостійне національне буття, на національну безпеку без вступу України в систему колективного евроатлантичного захисту. Хоча ідеологічні засади нашого державотворення нині, як і завжди, соціогуманістичні. Україна ніколи не була лише для українців, упівець ніколи не воював на землі іншого народу, не зазіхав на його землю, підступно називаючи це надаванням “братньої допомоги”. Не забуваймо цього і не спекулюймо на псевдоінтернаціоналізмі московитів-росіян, водночас приписуючи русинамукраїнцям - радикальний націоналізм. Адже духовно-інтелектуальна еліта українців завжди проповідувала соціогуманізм як ідеологію глобальної безпеки i periонального збереження національної ідентичности, закликала "i чужому навчатись, і свого не цуратись”, а УПА боролася “за волю людині й волю народам". Сто років тому Президент УНР Михайло Грушевський вважав українцем кожного, хто живе в Україні, любить іiі і працює задля добра українського народу. А Іван Франко ще у 1913 р. наголошував, що “потрібно витворити 3 величезної етнічної маси українського народу українську націю, суцільний культурний організм, здібний до самостійного культурного й політичного життя, відпорний на асиміляційну роботу інших націй, відки б вона не йшла, та при тім придатний на присвоювання собі якнайщирішою мірою і в якнайшвидшім темпі загальнолюдських культурних здобутків, без яких сьогодні жодна нація і жодна, хоч і яка сильна, держава не може остоятися"я.

На початку дев'яностих років XX ст. видавалося, що для Української Ідеї вже минув час утисків з боку сусідів і жорстокість боротьби, і вона, ставши основою державотворення, акумулює візію і очолить ходу нації в цивілізаційний світ. Натомість Україна і українськість - у небезпечній гібридній загрозі. Нібито зрозуміли, що для її національної безпеки потрібна сильна власна армія і надійний колективний евроатлантичний захист, сильна еконроміка. Але не обійтися і без соціогуманістичних стратегем розбудови національної держави Україна XXI ст., де українець, іiї патріот, захищає свободу, рідну мову, свою землю і традиції батьків, як поляк, француз чи інший европеєць свої власні. І ці патріотичні ідеологічні вартості безвідповідально називати націоналістичними, навіть тоді, коли цілеспрямовано і все життя шукати причетність нацистів до імпорту українських націоналістів і націоналізму. Лише засліплений ненавистю до України не бачить, що українські патріоти йдуть в Европу не лише з Бандерою, а $з$ великою культурою і багатим досвідом боротьби з тоталітаризмом XX і гібридною чумою ХXI ст.!

${ }^{9}$ Іван Франко, “Одвертий лист до галицької української молодежі”, Зібрання творів у 50 т., No. 45: філософські праці. (Київ: Наукова думка, 1986): 401-409. 
ISSN 2078-6077. Наукові зошити історичного факультету Львівського університету. 2020. Випуск 21. Proceedings of History Faculty of Lviv University. 2020. Issue 21.

Отже, навіть без високих студій зрозуміло: die Ukraine потрібен не більшовицький псевдоінтернаціоналізм, не німецький нацизм з поділом людей на Übermenschen und Untermenschen; не імперський націоналізм, густо замішаний на великодержавному шовінізмі та одержавленій церкві, а соціогуманізм як нова парадигма бінарного захисту людини і нації в контексті культурного розмаїття світової цивілізованої людности. Запропонована парадигма - це не лише ідея нової доби, вона диктує нову, соціогуманістичну форму відповідальности: розвивайся сам, допоможи чи принаймні не перешкоджай розвитку іншого. Ї̈̈ платформа акумулює і гармонізує три вектори розвитку української (і не лише української) спільноти: людиноцентричність (повага людини), націоцентричність (збереження ідентичности їі нації) та загальнолюдські цивілізаційні цінності як гідне використання досягнень цивілізованого світу для розбудови держави титульного народу.

Тоді, власне, будемо готові до ударів у спину; тоді перестанемо бути, як нам дорікав ще I. Франко, - “малими і неприготованими”; не матимемо регіональних президентів-зеків та втікачів, бо творитимемо справжню загальнонаціональну еліту, а президентів-патріотів готуватимемо $з$ дитинства - в сім'ях, садочках, інститутах та інституціях.

Урешті-решт, варто погодитися з прикінцевими словами Снайдера, що “коли ми дивимося у вічі Брекзиту, коли раз у раз спостерігаємо вибори з переможцямипопулістами, коли стикаємося зі зменшенням демократичности Сполучених Штатів - саме в цей момент Німеччина (і не лише вона - C. В.) не може дозволити собі помилково розуміти ключові питання своєї історії... Неправильне розуміння історії України тепер, коли Німеччина $є$ провідною демократією на Заході, матиме міжнародні (тяжкі світові - C. В.) наслідки... Нині для українців війна - це щось, що відбувається тут, а не десь там (колись відбувалося - C. В.)". Відповідальности вимагає не лише втручання Росії у виборчі процеси США чи деінде. Нещодавній марш польських націоналістів у Варшаві насторожив Европу. Европейська єдність важлива для всіх, аби не помагати творити посеред Европи (mitten in Europa) середовище, де в шафах наші сусіди далі ховатимуть скелети великодержавних шовіністичних ідей. Нехай мертві не тримають за руки живих. Націю творять “живі, мертві і ще ненароджені”. Ця Шевченкова максима тяглості суспільного розвитку має бути відрефлексована в контексті боротьби України “за нашу і вашу свободу” та вдячности світу за ії справжній інтернаціоналізм. 3 іншого боку, необхідне посилення відповідальности Заходу, що повинне виявлятися в допомозі протистояти поневоленню України гібридною війною, яку глобалізує Путін, а самозвані наші “брати” традиційно пофарисейськи подають світові “умиротвореним” українців як нібито нерозумних учасників внутрішньо-регіонального конфлікту. 
ISSN 2078-6077. Наукові зошити історичного факультету Львівського університету. 2020. Випуск 21. Proceedings of History Faculty of Lviv University. 2020. Issue 21.

\section{Припинити узурпувати історії націй та загарбувати їхнє майбуття}

Поневолювати інші нації американський історик назвав в Берліні - “звичками розуму”. Навряд чи поневолювати інші народи в спосіб “колонізації, агресивних воєн”, щобільше, приховуючи справжні загарбницькі наміри під всілякими брехливими брендами - інтернаціональне, братнє, тимчасове введення обмеженого військового контингенту, "умиротворєніє" тощо, - це винахід великого розуму, а не традиційно-захланних, загарбницьких мотивів та звички до брехні. I, як свідчить історія, відівчити від цих душевних девіяльноповедінкових звичок їхніх любителів дуже важко, не вдаривши спільно і боляче по відчутному місці самозваних “інтернаціональних альтруїстів”, які визнають лише силу, передовсім військову. До їхньої глибокої душі розумом не дістати, чи пак - ii “умом не понять”. Перероджена Німеччина й Україна це добре розуміють, тому і $є$ стратегічними партнерами. Канцлер ФРН Ангела Меркель активно допомагає припинити кровопролиття на сході України і є сподіваняя, що після чергової недавньої перемоги на виборах ії доброчинність не зменшуватиметься. На тлі розквіту в політиці ексцентриків, хочеться вірити в прийдешню духовноінтелектуальну еліту ноосферного рівня розвитку. Годимося, що "Макрон не напише офіційної історії Другої світової війни у Франції”. Але, як Президент Франції, може зробити Францію історично відповідальною, щоб недопустити ексцентриків розв'язати Третю; вплинути на виконання Мінських чи інших, справедливіших для України і чесних домовленостей, у яких відповідальними перед нею - без'ядерною - за деокупацію та терміни ії реалізації буде не лише Німеччина, а всі країни-підписанти Будапештського меморандуму. Небайдужий американський учений доходить правильного висновку, стверджуючи, що "російська зовнішня політика полягає в тому, щоб поділити історію Радянського Союзу на дві частини: добру частину, яка є російською, - i погану частину, яка є українською"... “Визволення - російське, колаборація - українська". Росіяни патріоти імперії, українці ж - націоналісти, хоча вони на своїй землі розвивають економіку своєї вітчизни, рідну мову тощо. Для українців такі перекручення неновина, але ж ті гібридні прийоми спокусили наших західних сусідів відкрити “другий фронт” проти бандерівців. Однак для нас має бути надважливим інше: історик Тімоті Снайдер глибоко проникає в речі, коли критикує імперськошовіністичні міти "про Україну як країну, яка не відбулась, або що українці не справжня нація чи що поділені культурою”; що “не є чимось невинним - це спадщина спроби колонізації людей, яких не вважали людьми”. Всілякі путіни і нині ненавидять українців-патріотів, їхню світоглядну іншість. Беззаперечно його дипломатам легко схилити світ “плутати Радянський Союз з Russland. Але це не $є$ невинним”. Доктор Снайдер також на висоті, коли застерігає Захід від нібито невинного поширювання російських нісенітниць, що, мовляв, “ніколи не було українського народу чи ніколи не було української держави”. Ненавидячи УНР, агенти Кремля навіть у Парижі вбили головного отамана ії військ, недавно їхні найманці розстріляли добровольця АТО - соліста Паризької Опери Василя Сліпака. 
ISSN 2078-6077. Наукові зошити історичного факультету Львівського університету. 2020. Випуск 21. Proceedings of History Faculty of Lviv University. 2020. Issue 21.

У такому контексті слушно очікувати, що пан Снайдер підкреслить потребу не плутати, паче того, усвідомлювати, відповідальність за зловмисно-неправдиве наповнення російськими політиками назви “Russland”, водночас розмиваючи “Die Ukraine”, категорично заперечуючи сенс іiі Національної Ідеї. Українці ждуть адекватної оцінки постверсальських (і не лише) небилиць кремлівських диктаторів про “русскую Анну”, що справді окультурила Францію. Однак вона, приїхавши до Франції з Києва, померла ще до фіксації літописцями географічної назви Москви як поселення племені угро-фінських мокшів на підмосковних болотах. Світ має нелише належно реагувати на не перші хибні згадки про княжну Анну Ярославну - дочку великокиївського князя Ярослава Мудрого як нібито далеку попередницю кремлівського неодиктатора Путіна, що прибув у Францію для того, щоб нібито продовжити давно започатковану культурну місію київських князів і княгинь. Час припинити імпершовіністичну брехню рекрута з рядів КДБ разом із попередніми “відвертими" його зізнаннями Президентові США Бушу-молодшому, що Україна, мовляв, ні історії, ні шматка своєї землі, ні власної державницької ідеї, ні мови - не має. Важливо, аби наші західні сусіди нас не принижували, вивчаючи боротьбу УПА в кадебістському тлумаченні, і не вимагали після півсторіччя ексгумації героїв, полеглих на своїй і за свою землю .

Нахабство Москви набуває розмаху і вимагає серйозних системних досліджень. Брехня, присвоєння історії Русі-України, зазіхання на землі сучасної Донеччини стали робочим інструментом російських неофюрерів, ознаками їх нецивілізованости, компенсаторами імперської агресивности, а також виявом комплексу ідентичної неповноцінности на грунті заздрости до високої культури давнього Києва та ненависти до життя-бугтя сучасних українців, до їх захисних евроатлантичних намірів, до імплементації европейських цінностей, кристалізації власних національних інтересів. Однак зазіхання Росії на право диктувати украӥнцям бути чи не бути їм вільною нацією не тільки не є причиною для Заходу, аби не думати про відповідальність перед Україною, а, навпаки, допомогти усвідомити загалові цю відповідальність як глобальну, нехтування якою може мати непередбачені наслідки для світу. Нікому не вдасться “вмити руки" від того, що Росія глобалізує гібридну війну, яка може перерости в Третю світову. І на цьомутлі боротьба Польщі за визнання лідерства у протистоянні з “русскім міром" - це давній синдром марнославства, віртуального “моцарства", і не більше. Чи не через нього занепали Велике - від Балтики до Чорного моря - князівство і нині належно не використовується співробітництво країн Балто-Чорноморської гряди, відсутній сектор східноевропейської політики ЕС? Головне нині - це мобілізація сил провідними демократичними країнами світу, синергіїнацій на боротьбу з інформаційними фейками та злом насилля військової агресії Путіна. Правда смертельна для нього і російської імперії. Щоби не спізнитися, треба якомога швидше усвідомити небезпеку “заплющування очей” на викиди “імперією зла" в ефір не лише пропагандистської “дези”, що Росія, мовляв, перемогла в минулому німецький нацизм, а зараз -терористів ІДІЛу. Адже в тумані “дези” важко уяснити, що насправді Путін підтримав тоталітаризм сирійського президента; чи, скажімо, що Росія ніколи не припиняла 
денаціоналізувати українців і викидати їх з рідних гнізд, прикидаючись такою собі невинною, мирною - "матрошно-окультуреною", природно інтернаціональною зозулею.

Західні сусіди України іï денаціоналізацію мовчки спостерігали і очікували. I нещодавнє прийняття закону “Про освіту”, за яким лише, як і належиться незалежній державі, навчання передбачається вести державною мовою, засвідчило: старе дає себе знати і ослабленій війною Україні важко знайти співчуття однодумців, каяття і милосердя. Навпаки, - вона зустріла “дружній” опір по всьому периметру свого прикордоння. Сусіди виявилися далекі від соціогуманістичних підходів відроджувати українську мову. Усі заодно з імперською Росією: щоправда, поки що заточені на відміну від їі псевдоінтернаціональнго російщення, регіонально - на подальше локальне ополячення Галичини, мадяризацію Закарпаття, румунізацію Буковини. Кожен окремо бачить свою частку поділу i, шкода, не задумується, що Росії потрібна не лише ціла "русская” Україна, не тільки весь простір поза нею, а й “вся Вселенная должна быть русской".

Отже, чи ліберальна спільнота західних сусідів досягнула критичної маси, необхідної для становлення лідерським політичним класом, чи далі лише допомагатиме загалові дотримуватися більш-менш достойного вигляду, без глибини альтруїзму і співчуття до російщення України, - покаже час. На ренесанс бажань нашого західного прикордоння повернути минуле ми звертали увагу давно ${ }^{10}$. Рівно ж - на оціогуманістичний бренд (соціо - суспільний, людський; гуманістичний людяний) як майбутній напрямок гуманітарної політики молодої України, як курс нових світоглядно-ідеологічних засад іiі державотворення, бінарного захисту уярмленої сусідами людини, коронної нації, зокрема іï̈ природного права безперешкодно передавати з покоління в покоління рідною мовою традиції батьків. Цей бренд не лише в сусідів не має урядової підтримки. Не все людське - виявилося людяним. Чи причиною є лише те, що Захід не припинив розплачуватися з Москвою даниною у вигляді надання права включати Київ, Мінськ, інші колишні радянські республіки в сферу “русского міра", тобто знову віддає на поталу і подальше розтерзання північному ведмедеві інші народи і народности? А, може, не хоче чути Масарика, Гавела, Гедройця, Куроня, Бзежинського? Чи не в стані усвідомити мудрий заклик Папи Івана Павла II: опертися в сусідських взаєминах на максимум каяття “прощаємо, і просимо вибачення" - як державно-непорушне, щиро-співчутливе та соціогуманістичне?

Чому серед чинників, які впливають на становлення кожної нації як державотворчої цілісної спільноти i, відповідно, можуть також комплексно застосовуватися і застосовуються в гібридній війні, щоб гальмувати процеси державотворення, не виділяємо хоча б умовно три великі блоки? Насамперед видимий - матеріяльний: територія, національна економіка, торгівля, об’єкти

\footnotetext{
${ }^{10}$ Степан Вовканич, Українці прикордоння: проблеми регіоналістики чи глобалістики. (Львів: Свросвіт, 1999), 416.

${ }^{11}$ М. Розумний, Виклики національного самовизначення. (Київ: НІСД, 2016), 196.
} 
ISSN 2078-6077. Наукові зошити історичного факультету Львівського університету. 2020. Випуск 21. Proceedings of History Faculty of Lviv University. 2020. Issue 21.

соціяльної інфраструктура тощо. Далі, духовно-інтелектуальний (освіта, наука, культура, релігія, суспільна пам'ять, традиції, національна свідомість, цінності, ментальність і т. ін.) та інформаційно-комунікативний (мова, засоби масової інформації та комунікації, видавнича справа, суспільні мережі та інститути, міжнародні зв'язки тощо). Вони - засадничі, коли формується нація, а загарбання чужої землі $\epsilon$ засадничо-злочинним, таким, що передусім визначає окупацію і відповідальність за неї. Власне, загарбники, завоювавши землю інших націй, заважають їм стати вільними і суверенними, в т.ч. нам, українцям. Саме нерозуміння націотворчої глобальности наведених основних чинників - велика завада досягти нині сталого порозуміння між сусідами, об'єднатися і забути історичні конфлікти перед загрозою глобалізації гібридизації. Але якщо чи то Росія не вибачається ні за геноцидний Голодомор 1933-1933 рр., ні за розстріли української еліти в Сандармоху; чи то Польща ні за порушення Сент-Жерменського договору щодо прав українців Східної Галичини, ні за “пацифікацію”, закатованих в “Березі Картузькій”, депортацію 3 рідних земель корінних українських субетносів - лемків, бойків, нищення їхніх культурних середовищ, то сутички між поляками на землі української Волині, дружба між пізнім Пілсудським та Гітлером, за якою ностальгують неонацисти, в т. ч. й польські, довготерміновий арешт Бандери чи вбивство нацистами в тюрмі не без поляків двох його братів - відходять на задній план і стають зручними для локальнопартійних маніпуляцій та спекулювання якоюсь “бандерівською ідеологією”. Реалії такі, що польські депутати, які проголосували за нібито “анти бандерівський” закон, кривлять душею, бо, насправді, виступили проти національно-визвольної змагань українського народу.

На жаль, польські партійці не без особистих зацікавлень підмінили поняття. Досягнутий цивілізацією абсолют прав людини, порядку і справедливості монополізували як бренд і послуговуються для підняття передвиборного рейтингу, роз'ятрюючи ненависть до борців за волю України, валять встановлені їм пам'ятники, насправді проти них на догоду Росії відкрито “другий фронт” наклепів тощо. Шкода, але захищені парасолькою НАТО, проповідники справедливости забули, як й пан Снайдер, що $є$ націоналізм соціогуманістичний - загальнолюдський, визвольнопатріотичний, а $є$ шовіністичний. Його рушійна сила - це великодержавність, етнічна зверхність, гонор аж до пихатості, схиблена расова вищість аж до ненависти "інших" (Велікая Россія, Польща від можа до можа, Румуне Маре; Львув - польске място, Севастополь - город русской славы тощо). Тут мотив - не захист і збереження в агресивному середовищі національної ідентичности поневолених націй, а анексія чужих земель, “обустройство” своєї буцімто священної, але, за світовою оцінкою, “імперії зла”; зазіхання на чужі “креси”, добивання сусіда і повернення до старого - щоб панувати над ним, ослабленим, в т. ч. і тобою. Той, хто поневолював українців, безвідповідально нині відкриває проти борців за волю України “другий фронт”, бездумно (чи навпаки, зловмисне) повторює за росіянами звинувачення в етнічному націоналізмі, у зраді мазепинців, петлюрівців; ба більше, у геноциді поляків на Волині - бандерівцями, уникаючи правди про їхню боротьбу за визволення своєї 
землі, рівні права для рідної мови, питомої культури. Лише очорнення боротьби, особливо очільника, що був ізольований в німецькому концтаборі (1941-1944), i цілковита мовчанка про низку важливих об'єктивних критеріїв: одна нація була панівною, мала власну державу, воювала на чужій, не своїй землі, а друга підневільна. Чи нез цієї причини поневолені нині непроголошують: міста Перемишль, Холм і т. д. заснували Київські князі? А можуть вдатися і до історичної правди тому уважно дивімося на передні і задні колеса довгого та непередбачуваного воза iсторії.

У цьому плані соціогуманізм охоплює також відповідальність однієї нації перед іншою, уможливлює суспільний діялог, щире каяття і прощення, нарешті, вимагає розрізняти націоналізму гноблених, громадський і громадянський моральнопсихологічний мотив яких - цезвільнитись від обіймів “старшого брата”, “отня i меча” сусіда, що придушував вільний дух українства, ділив і хоче далі ділить їх рідну матінку - землю. Прикро, що деякі недалекоглядні політикани раптом стали бачити продовження сторінок трагічної історії польсько-українських відносин лише на грунті свосї зверхности, колишнього “моцарства” і диктату, а не в стратегії дружньої майбутньої співпраці та нових рівноправних взаєминах двох сусідніх народів. Рашизм обопільно небезпечний, тому акцент має бути не на мартиролог давніх трагічних конфліктів, а на чинники майбутнього добросусідства! Шкода, що антиукраїнські сили створюють ілюзію, що вільна Польща можлива без вільної України, успішно, політизувавши історію, заграють з суспільним загалом задля піару своєї великопольськости; користуються не соціогуманістичним принципом - пробачаємо і просимо вибачення, а, як і колись, не кращим станом України, - стікаючої кров’ю у війні за звільнення своїх регіонів від російської навали.

Виокремлені вище блоки генези націй - комплексні і, окрім видимого важливого фактора землі, охоплюють в собі іще низку вагомих якісних характеристик і достоїнств, які внутрішньо притаманні людині та ії нації: національний рівень колективної свідомости, згуртованости як нації, демократизації політичного життя та, врешті, інтеграції в европейські, світові структури, темпи вступу в які детермінує креативний потенціял національних еліт, воля їхніх лідерів, патріотичність світогляду та оперативністю прийняття інноваційно-інтелектуальних рішень, широти мислення, прогресивність ідей та інших духовно-моральних якостей ${ }^{11}$. Саме вони надихнули українців усунути еліту, що зосередила необмежену владу в своїх руках, допомагають трансформувати екстрактивні інститути в інклюзивні, створити суспільство, де головною цінністю стануть рівні економічні та політичні права кожного. Власне, такі нації не занепадають, а, навпаки, досягають свободи і сталого добробуту ${ }^{12}$. Екстрактивні інститути грунтуються не на засадах визискування (екстакції, збирання

\footnotetext{
${ }^{12}$ Аджемоглу Дарон, Робінсон Джеймс. Чому нації занепадають. (Київ: Наш Формат, 2016), 440.

${ }^{13}$ Степан Вовканич, “Національна еліта та інтелектуальний потенціал України”. (Матеріали міжнародної наукової конференції “Національна еліта та інтелектуальний потенціал України”, Львів, Квітень 18-19, 1996).
} 
ISSN 2078-6077. Наукові зошити історичного факультету Львівського університету. 2020. Випуск 21. Proceedings of History Faculty of Lviv University. 2020. Issue 21.

вершків) політичними елітами підкорених народів або власного народу, що стимулює корупцію як сучасний інструментарій духовно-інтелектуального, культурно-інформаційного гноблення, обмежує політичну та економічну свободи і в такий спосіб серйозно гальмує інноваційний розвиток та цивілізаційний поступ. Тут українці сподіваються на судові реформи, створення доброчесних антикорупційних інституцій, децентралізацію влади і зростання місцевого самоуправління, суб’єкт якого - організовані територіяльні громади.

Ще в 1994 році ми провели міжнародну конференцію “Національна еліта та інтелектуальний потенціял України” (в якій, до речі, брали участь й польські науковці), яка показала важливу роль безперервности передачі знань (інформації) 3 покоління в покоління та творення нових знань на рівні однієї генерації для безперешкодного розвитку національної спільноти, ії прориву на передові інформаційні та ринкові простори ${ }^{13}$. Йшлося про так зване, згадуване вже, складне соціяльне явище духово-інформаційної мобільности (ДІМ) людини і нації. На жаль, розробку цієї проблематики не було продовжено. Попри те, економічні практики свідчать, що дифузія і емісія науково-технічної, технологічної, соціяльноекономічної та іншої передової (інсайдерської) інформації, запозичення досвіду топових країн світу далі матиме колосальне значення для конвергенції інноваційного розвитку і окремих регіонів України, i країни загалом. Власне, ця мета державотворення, судячи з виступів на економічному форумі “Давос-2018”, може глобалізувати синергію креативних людей, щоб провадити суспільні реформи, спільно творити фінансово-економічні, науково-технічні та інші новації в сьогоднішньому роз'єднаному світі та протиставити його загарбницьким силам, що хочуть далі визискувати інші нації для власного тотального домінування на ринкових просторах; для твердження своїх великодержавних імперськошовіністичних “міров”, генерування фейкової інформації, аби знову ділити світ за своїми хибними ідеями. Гібридна війна загрожує Україні не лише економічними, видимими територіальними втратами і безцінними людськими жертвами, а й духово-інтелектуальними (інформаційними) невидимим зомбуванням живих нематеріяльним міжпоколіннєвим пропагандистськобрехливим трансфером з великим лагом часу дії. Для обороноспроможности ослабленої держави, підвищення ефективности ії економіки дуже важать неекономічні чинники, яким український уряд не приділяє належної уваги.

Думаймо глобально: чи достатньо лише прийнятих економічних санкцій проти російського агресора та термінів їх дії, чи вистачить лише історичної відповідальности Німеччини, аби вільно і стабільно розвиватися українській нації в світовому розмаїтті економік, культур, інформаційних просторів?! Ці виклики відкриті та вимагають подальших студій. Тому надто важливо якнайшвидше зрозуміти, що кожній людині, нації й вже точно - людству, треба на них відповідати, щоб вижити. Треба “дати”, аби “бути”! Це виклик усім, передусім, відповідальности за майбутнє наше і світу, виклик ефективности евроатлантичного захисту соціогуманістичної концепції як планетарної. Власне, чи не соціогуманізм є тією глобальною концепцією нової доби, 
що синергійно може об'єднати спільно роботи добра - роз'єднаний світ? Саме в рамках глобальности цієї концепції складові УНІ, ставши стратегемами розбудови національної держави, спроможні допомогти українству не забуги істину: їхня країна на межіщоденного вибору між грубою гібридною силою тоталітаризму ісинергією креативу мудрости колективного захисту цивілізованоголюдства, його демократичних цінностей та відповідного доброчинства. Аби на “межі" зберегтися як нація, не втратити свою етнічну тотожність, власний імунітет (опірність) протистояти тотально-ідеологічній машині формування безадресного “советского человека", треба керуватися не тільки людино-націоцентричними цінностями, а й використовувати колосальний прорив цивілізованого людства в науково-технолого-технічній сфері. Від прориву треба нелише брати, а поповнювати та гідно збагачувати його спільний інформаційний тезаурус. Чи у світі для цього створюються рівні умови i, головне, чи розуміємо: Путіна ні Кримом, ні Донбасом, ні всією Україною - не задовольнити. Їх окупація - це лише знищення артефактів старту давнього злочину "обустройства" російської імперії, але далеко не фініш девіяльної поведінки нового ії маніяка світового калібру.

Отже, діяти належить нагально і в триєдиному контексті, як-то: гідности людини, нації та цивілізованого людства - його вселенського розмаїття економічних, соціяльних, духовно-моральних, культурно-мовних, безпекових та інших засад, традицій і цінностей. 3 цих позицій, власне, виходьмо й при регіональній деокупації України та опрацюванні комплексної стратегії розвитку іiї соборної держави на найближчу, середню і далеку перспективу, де наскрізний зв'язок між ними забезпечуватиме реалізація згаданих вище СУГестій як основних стратегем національної ідеї. Притримуймося засад цієї демократичної ідеї побудови нашої національної держави. До розв'язання проблем активніше залучаймо ООН, ii миротворчі інститути і сили, давно пора укласти з США договір про надання нам особливого статусу союзника поза межами НАТО. Нині міжнародна ситуація прихильніша до України, ніж вона була сто років тому за часів УНР. Захід більше поінформований про Росі і не дасть їй знову дурити світ, віддаючи українців та інші народи в сферу впливу відкритої кремлівської тюрми, котра впродовж свого існування перманентно "обустроивалася" i, нарешті, “обустроилася" в сталу імперію зла. Щобільше, у цьому напрямку і в XXI ст. вона “удосконалюється”, воюючи під прикриттям перефарбованої ідеології нового "русского міра", заохочуючи на побудову відповідних “світів” вождів Північної Кореї, ІДІЛу, підрозділів Аль Каїди і т. ін. Допоможімо українцям вистояти на "межі" з гібридно-зловісною війною! Світ, допомігши захистити суверенітет України, збільшить нелише синергію цивілізованого людства, а й глобалізує соціогуманістичну відповідальність за колективну безпеку загроженій імпершовіністами суб'єктності націй, за дотримання міжнародного правопорядку, транспарентності міждержавних відносин, субсидіярності прав окремої людини та прогресу людства планети Земля назагал. Це, врешті-решт, пришвидшить не лише вербальне, а й практичне втілення найвищої мегаморально-етичної максими людства: не чинити проти іншого народу того, чого не хотів би, щоб він робив ні тобі, ні цивілізованому світовому співтовариству. Рівно ж - зблизить комплексний розгляд феномену відповідальности не лише людини передлюдиною в трудових колективах, 
ISSN 2078-6077. Наукові зошити історичного факультету Львівського університету. 2020. Випуск 21. Proceedings of History Faculty of Lviv University. 2020. Issue 21.

громадських організаціях та суспільних інституціях, а й нації перед нацією в планетарному вимірі.

\title{
IS REGIONAL RESPONSIBILITY TO UKRAINE POSSIBLE WITHOUT GLOBALIZATION OF THE SOCIO-HUMANISTIC PARADIGM OF INTERNATIONAL RELATIONS?
}

\author{
Stepan VOVKANYCH \\ Institute of Regional Researchnamed after M.I. Dolishniy of the NAS of Ukraine \\ Department of Regional Economic Policy \\ st. Kozelnytska, 4, 79026, Lviv, Ukraine \\ e-mail:_irr@mail.lviv.ua
}

For the first time, attention is drawn to the fact that under Russia's escalation of hybrid war against Ukraine there is the urgent need for globalization of socio-economic, spiritual and informational, ethnocultural, legal and other responsibility of the West to Ukraine in terms of verification of a new sociohumanistic paradigm of international relations and application of the synergistic effect of civilized humanity as a result of the joint mobilization of human efforts in opposition to the current imperialchauvinistic challenges to global security, aggressive responses to the weakened nations' sovereignty and subjectivity. Besides the insufficient defence capacity and security from the well-armed invaders, these nations suffer from the criminal, crafty and hybrid-misinformative invader's voice, which makes them voiceless and doomed to be eternally unheeded.

This article was written in response to the publication in the journal "The Day" (July 7-8) the translation of speech of American historian Timothy Snyder's "Historical responsibility of Germany to Ukraine", which he made in the German Bundestag during discussion of relevant topics. This topic claims to analyze the period of both the Second World War and the modern military actions of the hybrid war imposed on Ukraine by Russia in its east. In view of this, a well-known American scientist, being a specialist in the history of Eastern Europe, in particular totalitarian regimes, should have broadened for the world the meaning of current struggle of Ukrainians "For our freedom and yours" in the Donbass. This omission during the escalation of threats to the globalization of Russia's hybrid war against Ukraine might have a critical impact for the unleash of the Third World War.

Instead, the responsible (irresponsible) behavior of the West is not evaluated, including these of Germany in relation to Ukraine at the 2008 NATO Summit in Bucharest, when it was not given an action plan for joining the Euro-Atlantic Alliance of Collective Defense, which could have made Russia's future military action against Georgia or Ukraine impossible. The cynical annexation of Crimea is not analyzed, as well as the need for timely and adequate reaction of the UN to the violation of international order, the costs Ukrainian pays for the hybrid war in the east, or the West pays for "anti-terrorist mission" of Russia in Syria, terrorist attacks in Paris, Brussels, an important number of migration problems source-related to the Putin neofuehrer policy, the restoration of the "Evil empire". Ukraine always has been the hostage of irresponsible West, because European policy of "closing the ears and eyes" on the Hitler Anschluss, playing the Ukrainian card in Transcarpathia, did not sunk into oblivion and has led in the XXI century to modern barbarism of Putin in Georgia, in the Crimea and east of Ukraine.

Typically, the West traditionally paid tribute to Russia, sacrificing the state independence of Ukraine. Therefore, considering historical responsibility to Ukraine, historian Snyder would have distinguish, among the many reasons for such unfair realities, at least three, probably the most important, ones. First of all, the West never deliberately distinguished the mediatory role and weight of Ukraine as one of the priority factors in the structure of the stabilization of international security, which would have to extend, according to the plans of the parents of the EU - de Gaulle and Adenauer - to the Ural. Secondly, it never had a strategy regarding Ukraine as an important factor in the mechanism of spreading 
Euro-Atlantic values to the Eurasian expanses. Moreover, the West has always been easily blinded (or it was blinded) by the aureole of Russia as the "advocate" of these values in Ukraine, Georgia, and other countries of its domination, where freedom was actually suppressed, European values were destroyed and world order was violently clashed. The third one looks to be the most worst thing, because it does not mention by the American historian either. Ukraine as a state had not effectively used and do not use now the right to remind the world that it is not properly appreciate the truly international dimension of the Ukrainian fight "for our freedom and yours", conquered by the cost of the lives Heroes of Kruty, Holodnuj Jar, Ukrainian Insurgent Army, Celestial Hundred, Euromaidan defenders and ATO.

Russia further fools the world, traditionally demanding the usual tribute. Is it not time to wake up and realize the bitter truth: the appetite of Russia will never end with the occupation of Ukraine only? Russia wants to become a center of Eurasia, which will cover the entire European continent. Unfortunately, Dr. Snyder is not worried about the lack of adequate reaction to the nasty ruscism as the neo-imperial global model of the implementation of aggressive chauvinistic ideology of "Russian world". He does not help to understand another obvious and extremely necessary thing: the testing of Ukrainians by hybrid war is Russia's attempt to unleash the same, but as the Third World War. So, for the whole world it is not only a hybrid, but also an pilot warfare, in which the conquest-imperial methods of global domination of the crazy state-church ideologues of another world - "Russian", falsely-insidious-cynical, are thoroughened in the Donbass. Today's "decomposition" of Ukraine in the East, its federalization - is the possible fragmentation of the EU tomorrow.

Throughout the speech emphasizes the responsibility of Germany for allegedly spreading of Ukrainian nationalism with such force, that the voice of dying today in eastern Ukraine patriots who heroically fighting against Russian mercenaries, giving their lives for the freedom of civilized mankind, is deafen. It is amazing even with the amendment that the speaker "made his career writing about the Ukrainian nationalists". It is difficult to fully agree with the reflections: "Ukraine is the cause of the war; if Hitler had no colonial idea to go to war with Eastern Europe, if there were no such a plan, there could not be a Holocaust "(?). It's truly to say, that author pay tributes to the numerous victims of the Ukrainians fight against Nazism, the idea of Hitler to create an Eastern Europe center, based on the slavery, the colonial regime of destruction and enslavement of Ukraine. However, the speaker, oftenly as a good mentor, tries to "enrich" the memory of the young historical concept from an arsenal of his own "scientific" discoveries: "Ukrainian nationalism, the Ukrainian nationalists (which are the consequence of the German war in Eastern Europe) were the cause - or one of causes - the Great Famine of 1932-1933". And not just the Great Famine . "Ukrainian nationalism was one of the causes of the terror of 1937-1938." It was "one of Stalin's reasons for the deportations of the inhabitants of Soviet Ukraine after the Second World War." And the conclusion: "Ukrainian nationalism was the reason for Russia's invasion of Ukraine in 2014"?!

Keywords: historic responsibility to Ukraine, national idea, socio-humanistic paradigm, stratagems and maxima of the country's development.

\section{References}

Adzhemohlu Daron, Robinson Dzheims. Chomu Natsii Zanepadaiut. (Kyiv: Nash Format, 2016), 440.

Vovkanych, Stepan. “Aksiolohiia derzhavotvorchykh protsesiv za umov sotsialno-ekonomichnykh zmin: novykh vyklykiv i zahroz natsionalnii bezpetsi”, Stratehichna panorama, No. 1, (2015): 76-83.

Vovkanych, Stepan. 'Natsionalna elita ta intelektualnyi potentsial Ukrainy”. (Materialy mizhnarodnoi naukovoi konferentsii "Natsionalna elita ta intelektualnyi potentsial Ukrainy", Lviv, Kviten 18-19, 1996). 
ISSN 2078-6077. Наукові зошити історичного факультету Львівського університету. 2020. Випуск 21.

Proceedings of History Faculty of Lviv University. 2020. Issue 21.

Vovkanych, Stepan. Ukraintsi prykordonnia: problemy rehionalistyky chy hlobalistyky. (Lviv: Yevrosvit, 1999), 416.

Vovkanych, Ctepan. “Chy lyshe odna Nimechchyna vidpovidalna?”, Ukraina moloda, No. 118 (5279), 3 zhovtnia 2017.

Horbulin, Volodymyr uklad. Donbas i Krym: cina povernennya (Kyyiv: NISD, 2015), 474.

Pushkaryk, Natalia. "Pro pomylky mynuloho i ...sohodennia" (Materialy mizhnarodnoi konferentsii VR Ukrainy "Nimechchyna ta Ukraina v Yevropi: vidpovidalnist za mynule oboviazky na maibutnie", 2017).

Rozumnyi, M. Vyklyky natsionalnoho samovyznachennia. (Kyiv: NISD, 2016), 196.

Snaider, Timoti. “Istorychna vidpovidalnist Nimechchyny pered Ukrainoiu”, Den, No. 115$116,(2017)$.

Franko, Ivan. "Odvertyi lyst do halytskoi ukrainskoi molodezhi”, Zibrannia tvoriv u 50 t., No. 45: filosofski pratsi. (Kyiv: Naukova dumka, 1986): 401-409. 